\title{
THE BACKGROUND OF THE WAGNER NATIONAL HEALTH BILL
}

\author{
HaROLD MasLOW*
}

The introduction of Senator Wagner's National Health Bill ${ }^{1}-S$. $x 620$, to use its legislative tag-topped off-a series of earlier efforts in the direction of health reforms. The bill itself-the administrative machinery provided and its content-is by no means novel but is based on earlier experience. Behind all the studies, the conferences, the legislative battles, the earlier enactments and efforts, lie a group of socio-economic forces which may be considered the "real causes" for these various happenings. The treatment of these earlier endeavors at health reform will, for the sake of clarity, be divided into a chronological account of the general efforts, and a description of the previous administrative experience in the special fields covered by the Wagner Bill. The broad societal forces in the background will be sketched separately.

\section{The General Efforts in the Background}

A history of the modern attempts at health reform is usually begun with the lively health insurance movement about the time of the World War. This movement was primarily set off by the passage in I9II of the British health insurance law. ${ }^{2}$ Compulsory health insurance bills were introduced in a dozen legislatures, and some of them appointed legislative commissions to investigate the proposal. Several commissions gave a favorable report, but no bill was passed, although New York came within a few votes of enactment. By rg2I interest had died down. According to Rubinow, who played an active part in this early movement, the main cause for the failure to enact any law was the inclusion of a small funeral benefit in these bills. This clause brought on the powerful opposition of the industrial insurance companies whose business is recognized as being essentially burial insurance. The American Medical Association did not either officially oppose or approve the legislation; some

\footnotetext{
- B.A., 1937, University of Wisconsin. Formerly, staff member of the Committee on Rescarch in Medical Economics, and of the New York State Temporary Comm'n to Formulate a Long Range Health Program. Author of articles on medical economics and family allowances.

${ }^{1}$ S. 1620, 76th Cong., rst Sess., introduced Feb. 28, 1939, is comprised of five sections. Section I states the purpose and popular title of the Act; $\$ 2$ amends Title V, parts I, 2, and 5 of the Social Security Act; $\$ 3$ amends Title VI; $\$ 4$ adds new titles XII, XIII, and XIV to the Act; $\$ 5(a)$ amends $\$ 1$ ror (a)(1), (2); $\$ 5$ (b) adds a new subsection (e) to $\$ 1$ Ior. In this article citation hereafter will be made to the title, part, and section numbers of the Social Security Act, as amended by the bill, rather than to the section numbers of the bill.

${ }^{2}$ National Insurance Act, I9I I, I \& 2 Geo. V, c. 55.
} 
of the component state and county medical societies vigorously opposed, but some approved the proposal. While the American Federation of Labor conventions also took no stand, the weight of President Samuel Gompers and the Executive Council was definitely placed against the measure. Some state federations of labor followed Gompers's strong anti-state philosophy and disapproved. Others, such as the New York federation, energetically pressed for the legislation. The American Hospital Association and the National Organization for Public Health Nursing endorsed compulsory health insurance at this time. ${ }^{3}$

Interest was also shown in federal grants for public health work in the states during this period. The Chamberlain-Kahn Act, ${ }^{4}$ passed in 1918; set up a system of federal grants for state venereal disease programs. Senator France, a Republican and a physician, introduced in 1919 a bill which provided for federal public health grantsin-aid of $\$ 15,000,000$, and federal grants for hospital construction of $\$ 48,000,0000^{5}$ That same year, Representative Mann introduced a bill providing federal grants of $\$ 1,000,000$ a year for rural public health work..$^{6}$

The public psychology in the halcyon 'twenties was not favorable for a consideration of social problems and little was heard of health reforms. The American Medical Association in I92I formally denounced compulsory health insurance. Congress permitted the federal program of venereal disease grants to lapse, but in 192I, after several years of strong public agitation, it enacted the Sheppard-Towner ${ }^{7}$ Bill for federal grants to state infant and maternal hygiene plans. The decade was marked by a development of interest on the part of the private foundations: the Commonwealth Fund and the Milbank Memorial Fund demonstrations showed, by actual practice, the life-saving possibilities of our modern public health science. It is of some interest to quote from a rg2r editorial by Dr. Glenn Frank, now chairman of an official committee on whose report the Republican Party will presumably base its I940 platform:

"A quit-claim deed to immortality is awaiting the surgeon, physician, or statesman who can think of health in terms of a nation instead of a patient, and who can effect the beginnings of a national-health program that will insure to every man, woman and child in the United States the full and continuous benefits of the best in medical science and service."8

Dr. Frank then went on to advocate a system of complete state medicine which is today considered as too radical and impractical.politically by students of the subject.

Several foundations provided the initiative and a $\$ 1,000,000$ grant for the Committee on the Costs of Medical Care which launched a five-year, comprehensive, factfinding program after its formation in 1927. The chairman of the CCMC was Dr. Ray Lyman Wilbur, a former AMA president and a Hoover cabinet member. The 28 volumes produced by the CCMC up to 1932 gave a tremendous fillip to dis-

\footnotetext{
${ }^{3}$ See Rubinow, Quest for Security (I934) 207-217; Millis, Sickness and INSURANce (I937) II8-121.

40 Stat. 886 (Igr8).

H. R. 10510, 66th Cong., Ist Sess. (19r9).

S. 2507, 66th Cong., Ist Sess. (19r9).

42 STAT. 224 (I921).

${ }^{8}$ Trailing the Robin Hoods of Medicine (I92I) 102 (N. S. 80) Century Magazine 955.
} 
cussion of the health problem, especially in professional circles. The majority report of the Commitiee made the following recommendations: ( $\mathrm{I}$ ) the expansion of group practice through hospitals or group clinics, (2) a marked extension of public health work, (3) the development of group payment for medical care through insurance or taxation, and (4) the formation of agencies to co-ordinate the community health resources. It was also suggested that federal grants be made for medical care in the poorer states. ${ }^{\ominus}$ Aside from its broad intellectual stimulation, the CCMC was an important factor in influencing the American Hospital Association to endorse group hospitalization in 1933 and in inducing a greater medical society interest in the organization of plans for medical care.

President Roosevelt in 1934 appointed the Committee on Economic Security to draft a Social Security Bill. The general understanding was that the Committee would include a health insurance title, but when the bill was presented to Congress no such measure was provided. ${ }^{10}$ The active opposition of the American Medical Association is usually recognized as the cause for this omission. However, an ambitious program of federal grants for public health work, infant and maternity hygiene, and crippled children care was provided by the Act. At the extensive social security hearings, practically no opposition was voiced to these titles of the bill. The American Medical Association did not appear at the hearings. The 1939 Congress readily provided increased appropriations for these federal grants under the Social Security Act, when the states evinced a desire for further expansion.11

As regards medical care, the main development since the CCMC has been in the field of voluntary health insurance, especially group hospitalization. The federal government, through the Farm Security Administration, has worked out a hybrid voluntary-governmental, insurance-relief, medical care program for the FSA clients. In the states, compulsory health insurance bills are once again being introduced in noticeable numbers. The California State Medical Society in 1935, when the local political temper made a compulsory law a definite possibility, formally endorsed such legislation, although this position has since been changed. Wisconsin is another state where health insurance is being actively discussed. The recent passage of a law in British Columbia has had some influence in the states, and bills which slavishly follow that enactment have been introduced in Massachusetts and Washington. The American Association for Social Security Model Bill has also been introduced in several states. In New York State, the 1938 constitutional convention approved an amendment that would make constitutional the enactment of a compulsory health insurance law, and when this amendment ${ }^{12}$ was submitted to the voters, it received

\footnotetext{
${ }^{9}$ Committee on the Costs of Medical Care, Medical Care for the American People (1932) 122.

${ }^{10}$ For a discussion of the health insurance problem, see Commitree on Economic Security, Report TO THE President (I935) 4I-43.

11 Pub. No. 379, 76th Cong., Ist Sess. (1939) tit. V. See Sen. Comm. on Finance, "Social Security Act Amendments of 1939," Sen. Rep. No. 734, 76th Cong., Ist Scss. (1939). Also, Sen. Comm. on Finance, "Hearings on Social Security Act Amendments," H. R. No. 6635, 76th Cong., Ist Sess. (1939) p. 423. See Miss Lenroot's comments at bottom of p. 43I.

${ }^{12}$ N. Y. Const. art. VII, $\$ 8$.
} 
the largest vote of any of the proposed amendments. This state has a legislative commission now studying health insurance.

In 1936 the American Foundation conducted a survey of opinion amongst a cross-section of the medical profession, and much interest has been shown in the resulting two volumes published by the Foundation. ${ }^{13}$ They reveal an amount of individual professional approval for the various forms of socialized medicine which. is surprising in view of the opposition by the most important organization of doctors, the American Medical Association. As a direct outcome of this study, the important Committee of Physicians for the Improvement of Medical Care was formed, composed of a small group of prominent physicians, whose purpose seems to be to influence the AMA away from its conservatism. This Committee appeared at the hearings on the Wagner National Health Bill in favor of the measure. ${ }^{14}$

Immediately after the passage of the Social Security Act, the President appointed an Interdepartmental Committee to Co-ordinate Health and Welfare Activities. This Interdepartmental Committee, under the chairmanship of Miss Josephine Roche, then Assistant Secretary of the Treasury, duly appointed a subcommittee, the Technical Committee on Medical Care, to continue the studies in medical care of the I934 Committee on Economic Security. The Technical Committee, in February I938, submitted two reports, "The Need for a National Health Program," and "A National Health Program,"15 in which it sketched a picture of lag in bringing to the people the many new developments in the medical sciences and proposed a ten-year plan for a progressively increasing program of federal grants to encourage health work in the states. The President suggested that the National Health Program be placed before a public conference and, accordingly, in the hot summer of 1938 , about 200 leaders in American life representing the professions, labor, farmers, and various civic organizations, came to the memorable National Health Conference. It is generally agreed that the dominant note was a definite approval of the National Health Program, although the American Medical Association disapproved the plan. ${ }^{16}$ Probably the main significance of the National Health Conference lies in the fact that it actively brought into the discussion of health reforms, thus far largely monopolized by the professional groups, such lay organizations as the American Federation of Labor and the American Farm Bureau Federation, which play a large role in the shaping of legislative policy. Since the National Health Conference, the tendency has been generally to accept the existence of unmet health needs and to focus public discussion upon the problem of selecting techniques for meeting these needs.

The President sent the reports of the Technical Committee to the I939 Congress

${ }^{13}$ American Foundation, American Medicine: Expert Testimony Out of Court (i937).

24 Hearings before a Subcommittee of the Senate Committee on Education and Labor on S. I620, ("to Establish a National Health Program") 76th Cong., Ist Sess. (1939). (Hereinafter cited as "Hearings on S. 1620.")

${ }^{25}$ The reports were transmitted with a message from the President of the United States to the Congress, January 23, 1939. H. R. Doc. No. I20, 76th Cong., Ist Sess., reprinted in Hearings on S. I620, at I7.

20 Interdepartmental Committee to Co-ordinate Health and Welfare Activities, Proceedings, National Heatth Conference, July $28,19,20,1938$. 
with a message recommending their "careful study," and, subsequently, Senator Wagner introduced S. 1620 which substantially incorporated the National Health Program. A subcommittee of the Senate Committee on Education and Labor conducted unusually extensive hearings ${ }^{17}$ on the bill at which various labor and farmer groups appeared in favor of the measure, while the American Medical Association appeared in opposition. In August 1939, Senator Murray of Montana submitted a preliminary report for the subcommittee which stated that the subcommittee "is in agreement with the general purposes and objectives of this bill," but that "additional study" is desirable, and that "the subcommittee intends to report out an amended bill at the next session of Congress."18

\section{The Spectal Experience in the Background}

Significantly, the Wagner Bill takes the form of amendments to the Social Security Act, and a good deal of the bill provides for merely an expansion of the existing health titles of the Act. ${ }^{19}$ In the fields untouched by the Act, but covered by the bill, there is also a substantial body of precedent. This background of experience will be examined in connection with each type of aid proposed by the bill.

Grants for Maternal and Child Welfare. The federal government passed in r92r the Sheppard-Towner Act ${ }^{20}$ which provided grants to the states for maternal and child health, a system that was continued until r929. At the I921 hearings ${ }^{21}$ on that bill, the proponents pointed to a high infant and maternal death rate, especially in rural areas, as compared with other countries. Various demonstrations had shown that the death rates could be reduced, but the necessary techniques were not being extensively applied. It was urged that federal grants would greatly encourage their adoption in the states. The Catholic Social Welfare Council, the AFL, the National Consumers' League, and other organizations appeared in favor of the bill. President Harding recommended its passage in his message to Congress. The opposition to the measure came from several state medical societies and anti-women's suffrage clubs. The opponents argued the need for tax economy, the inadvisability of federal control of local health work, and the possibility of lay control. Some friends of the bill opposed its administration by the Children's Bureau of the Labor Department instead of by the Public Health Service, and, accordingly, the Act, as passed, provided for a Federal Board of Maternity and Infant Hygiene, composed of the Surgeon General of the Public Health Service, the Federal Commissioner of Education, and the Chief of the Children's Bureau, that was to lay down the regulations by which the Children's Bureau dispensed the grants. The Act gave an annual appropriation to the Children's Bureau of $\$ 1,240,000$ for this work.

\footnotetext{
${ }^{12}$ See note 14 , supra.

${ }^{18}$ See Hearings on S. 1620; Senate Committee on Education and Labor, "Establishing a National Health Program," SEN. Rep. No. 1139, 76th Cong., Ist Sess. (1939) 1.

${ }^{10}$ See note I, supra.

${ }^{21}$ Hearings before House Committee on Interstate and Foreign Commerce on H. R. 2366, 67th Cong., Ist Sess. (rg2r); Hearings before Senate Committee on Education and Labor on S. r039, 67th Cong., Ist Sess. (1921):
} 
During the Sheppard-Towner period, almost 3,000 new permanent centers for child health or maternity hygiene, or both, were established. This represented a great development of the child health center idea, which has been traced back to the Strauss Infant Milk Stations, first organized in New York City in I893. In I9Io, only 42 organizations located in thirty cities were maintaining baby health stations. The Act appears to have definitely stimulated maternal and infant work, which, however, abated somewhat after the federal grants ceased. In $1928, \$ 2,158,000$ was spent for these activities of which the states supplied about $55 \%$, while in I934 the states were spending only a million dollars in this field.

Strong efforts were made to renew the legislation after Congress allowed it to lapse in I929, but they were not successful in the face of the reigning political conservatism. The American Medical Association opposed continuation of the system in the sweeping terms of a resolution of its House of Delegates: "Resolved that the House of Delegates condemns as unsound in policy, wasteful and extravagant, unproductive of results and tending to promote communism, the federal subsidy system established by the Sheppard-Towner Maternity and Infancy Act and protests against a renewal of that system in any form."22 Appearing against the bill at the hearings in the 7rst Congress, were the Sentinels of the Republic, the Woman Patriots of Massachusetts, and the AMA.

Title V of the 1935 Social Security Act revived the Sheppard-Towner system but on a much greater scale, providing $\$ 3,800,000$ for the work. In its administration, the Children's Bureau has been emphasizing the basic machinery for state programs, such as the establishment of a maternal and child health division in each state health department, extension of public health nursing, and the development of training courses for doctors and nurses. According to Miss Katherine Lenroot of the Children's Bureau: "As developed up to the present time with the limited financial resources available, the program is chiefly one of health education and health supervision." 23 Relatively little has been done in regard to medical care at childbirth, nutrition work and social work. The states submitted plans for r939, approved by the Children's Bureau, totalling $\$ 4,229,000$, well in excess of the federal-appropriation.

Congress in 1939 increased the appropriation for this work to $\$ 5,820,000$. $^{24}$ The Wagner Bill would provide the sum of $\$ 8,000,000$ for the first year after its enactment, $\$ 20,000,000$ for the second year, and $\$ 35,000,000$ for the third year. ${ }^{25}$

Federal Grants for Crippled Children Programs. Immediately preceding the passage of the Social Security Act, 35 states were spending about five and a half million dollars per year for locating, diagnosing, and treating crippled children, most of whom were paralytics. No federal aid had ever been given for this work until the Social Security Act appropriated $\$ 2,850,000$ for federal grants-in-aid. ${ }^{26}$ Today all the

\footnotetext{
${ }^{32}$ Hearings before the House Committee on Interstate and Foreign Commerce on S. 255 and H. R. 12955, 71st Cong., 3d Sess. (1929) 173.

${ }_{18}$ Health Security for Mothers and Children (March, 1939) 202 Annals 107.

"Pub. No. 379, 76th Cong., Ist Sess. (1939) \$50r.

${ }^{15}$ Nat. Health Bill, tit. V, pt. $x$, 5501 . (Appropriations are merely authorized by the Bill.)

20 Although Senator Copeland introduced in 1930 two bills concerning federal grants to state crippled
} 
states have crippled children programs, and they are more liberal than formerly in regard to age and income eligibility requirements. In the first years of this federal program, the full annual appropriation was not used up, but the budget requests from the states for 1939 exceeded it. The 1939 Congress increased the appropriation to $\$ 3,870,000 .{ }^{27}$ The Wagner Bill would provide the sum of four million dollars for the first year, and five million dollars for the second year. ${ }^{28}$ The Wagner Bill would provide a still larger sum for "medical care of children," 29 in addition to the crippled children work.

Federal Grants for Public Health. The federal government, through the United States Public Health Service, has for many years stimulated state and local public health work, and national leadership is today generally expected from the Service. Its leadership has been exerted through the annual Conference of State and Territorial Health Officers since 1902, the publication of bulletins and reports, the creation of standards for public health work, special field surveys, demonstration projects, and finally grants-in-aid.

The Public Health Service conducted a program of demonstration projects in the states after I9I7 for which Congress appropriated about $\$ 300,000$ in its later years. Where a state or locality agreed to share the costs of a demonstration, the Public Health Service would set up a project in the hope that the locality would take over the whole expense at the end of the demonstration period. It is an easy transition from such a program to regular, continuous grants-in-aid.

The Public Health Service conducted a federal grants-in-aid program for state venereal disease work under the Chamberlain-Kahn Act of $1918 .^{30}$ This law marks the first application of the grants-in-aid device to the field of health. Congress appropriated $\$ \mathrm{x}, 000,000$ a year for grants to the states, but steadily reduced this sum after 1920. By 1925, no appropriation at all was being made to continue the program, although practically no opposition had been voiced against the passage of this law, and no friction had developed between the state and federal health authorities in its administration. ${ }^{31}$ The conservative political temper and the puritanical social attitudes still prevailing in the twenties appear to have led to the cessation of the system. In 1938 , after an intensive syphilis education movement with which the Surgeon General, Dr. Thomas Parran, was closely associated, Congress again set up the system, ${ }^{32}$ but on a broader scale, providing $\$ 3,000,000$ a year for the work. At the hearings on the bill, nobody appeared in opposition, while several doctors and a state medical society appeared in favor of $\mathrm{it}^{33}$

children programs, one of which provided three million, and the other six million dollars. S. 3336 and S. 3639,71 ist Cong., 2nd Sess. (1930).

${ }_{37}$ Supra note $24, \$ 504$.

${ }^{28}$ Nat. Health Bill, tit. V, pt. 2, $\$ 512$.

so Ibid. $\$ 9,000,000$ is authorized for the first year, $\$ 11,000,000$ for the year following. For subsequent years a total appropiriation of $\$ 35,000,000$ is authorized, to be divided between the two purposes in such proportions as the Children's Bureau deems necessary.

31 Leigh, Federal Hearth Administration (1927) 405-412.

${ }^{80}$ Supra note 4 .

${ }^{33}$ Hearings before the Senate Committee on Interstate Commerce on S. 3920, 75th Cong., $3 \mathrm{~d}$ Sess. (1938). 
The I935 Congress which enacted the Social Security Act was presented with some evidence of a breakdown in public health work in the states due to the depression. The Federal Emergency Relief Administration took the unusual step of giving $\$ 1,000,000$ to the Public Health Service for aids to rural public health work. ${ }^{34}$ Title VI of the Social Security Act provided $\$ 8,000,000$ a year in grants to the states for public health work, and much progress has followed these grants. On January I, I935, 594 out of our 3000 counties 'were being served by a full-time health officer, while at the close of 1938 this useful index of public health work had jumped by more than $100 \%$ to $137 \mathrm{I}$ counties. This federal money has gone mainly towards the erection of the basic state and local health department machinery; little has been done in the way of developing such special services as industrial hygiene. Ample testimony was given at the hearings on the Wagner Bill that this co-operative program is being conducted with no friction between the states and the Public Health Service. ${ }^{35}$

The 1939 Social Security Act amendments included an increase of the federal appropriation for general public health grants to $\$ 11,000,000 .^{30}$ The Wagner Bill would provide amounts for public health grants which are several times larger than this appropriation. ${ }^{37}$

Grants for Hospital and Health Certer Construction. The modern hospital has become essential to a high quality of medical care in a community. The hospital of today is a workshop for the doctor, a medical research center, a post-graduate school for the practitioner, a training place for young internes and nurses, and sometimes a center for public health work. The rural health center may be considered as a substitute hospital, not having all the facilities of the latter, but suitable for sparsely settled areas which cannot afford a hospital.

State and local governments have, for many years, assumed the burden of hospitalizing the sick poor, especially for the expensive chronic ailments. It is widely recognized that they have lagged lamentably in the proper provisions for the tuberculous and the mentally ill. Churches, fraternal orders and community associations have built many general hospitals operated on a non-profit basis, which specialize in caring for those able to pay although they have a long tradition of also caring-for charity cases. Since about $70 \%$ of the funds of the voluntary hospitals comes from patients' fees, these institutions are hard hit by a depression. The widespread practice of giving tax funds to voluntary hospitals for the indigent cases, may eventually be developed as an important depression bulwark for this group of hospitals, and in this connection, the provision of the Wagner Bill concerning federal grants for medical care $^{38}$ has definite potentialities.

The federal government, through the Public Works Administration and the

${ }^{34}$ Surgeon General of the Public Health Service, AnN. Rep. 1935, p. 67.

${ }^{35}$ See, e.g., the testimony of Abel Wolman and Dr. Felix Underwood, Hearings on S. I620, pp. 130I39, 540-542.

${ }^{86}$ Supra note $24, \$ 509$.

${ }^{37}$ Nat. Health Bill, tit. VI, pt. I, $\$ 60$. The amount authorized for the first year is $\$ 15,000,000$; for the second year, $\$ 25,000,000$, for the third year, $\$ 60,000,000$.

${ }^{38}$ Nat. Health Bill, tit. XIII. 
Works Progress Administration, entered the field of hospital construction as a part of its broad re-employment program. Since 1933, PWA has helped construct new hospitals, extend old ones, and install modern equipment in inadequate institutions. These projects have provided 51,000 additional hospital beds, an appreciable dent in the problem caused by the falling off of hospital construction in the depression. PWA makes grants and also lends money to governmental bodies for construction purposes. From 1933 to 1936 , PWA allotted $\$ 75,000,000$ for hospital construction, about two thirds of which was in the form of grants, and the other third in loans. ${ }^{38}$

WPA has also done some work in the hospital field, mostly the repair and renovation of existing institutions. From 1935 to 1938, WPA constructed ror new hospitals, built additions to 38 , and improved $1,422 .{ }^{40}$ WPA provides the labor, while the sponsoring governmental body supplies the materials and the land. WPA has also had some health center projects, notably those in New York City. The need for a hospital project is taken for granted by WPA, for it is assumed that the substantial local contribution required will assure only worthy projects. It is important to note that both WPA and PWA are not federal construction programs, for all projects, aside from the necessity for the sponsor's contribution, are initially requested by a local or state government body.

The Wagner Bill provides federal grants for general hospital construction totaling over $\$ 150,000,000$ for the first three years, ${ }^{41}$ or about twice as much as PWA allotted for all hospital work in a comparable period. In addition, a "sufficient" amount is to be appropriated for the building of more mental and tuberculosis hospitals. The Wagner Bill specifically authorizes the Public Health Service to utilize the experienced Federal Emergency Administration of Public Works in developing this program. ${ }^{42}$

Grants to States for Medical Care. This title of the Wagner Bill ${ }^{43}$ would provide federal grants to state health insurance systems in the ordinary meaning of the term, to state systems of public medical care for the whole population, or to state plans for medical care of the needy, according to the wishes of the individual state.

Public medical care has been provided by the state or local governments to indigent persons since colonial days. Non-governmental agencies, especially the medical profession, have also dispensed free care to the needy, but the treatment of the indigent has become more and more a governmental function. Over the years, the state and local units of government have developed varying patterns of administration of public medical care, with a wide range in standards. In the bottom of the depression, these programs were threatened with disaster because of the great increase in the relief population and the corresponding fall in tax receipts. Accordingly, in 1933 the federal government for the first time, entered the picture of medical care

${ }^{38}$ Fed. Emergency Adm'n of Public Works, PWA Provides Modern Hospitals (1937).

${ }^{\circ}$ Works Progress Administration, Release No. 14329, Physical Accomplishments on WPA Projects through June 30,1938 .

${ }^{11}$ Nat. Health Bill, tit. XII, $\$ 1201$. Part of the sum authorized is to be used to "assist the states for a period of three years in defraying the operating costs of added facilities."

${ }^{2}$ Id. $\$ 1203(\mathrm{c})$.

ss Nat. Health Bill, tit. XIII. 
for the needy through the famous Regulation No. 7 of the Federal Emergency Relief Administration. This administrative regulation stated that sickness care was a legitimate form of relief and that the regular federal program of grants-in-aid to the states for relief would also cover state programs for medical care in the home. The federal grants were to be confined to the severe emergency sicknesses, and were not to be used for hospitalization. By September, I934, twenty states had programs in accordance with Regulation No. 7 , thirteen states had partial programs, eight had none, and eight had continued their former systems. ${ }^{44}$ When the federal government in 1935 assumed the care of the able-bodied unemployed through WPA, and left the remainder of the unemployed for the states and localities, this federal program for indigent medical care ceased. General relief standards have fallen since 1935, and it is to be expected that the medical care programs have especially suffered, since the hard-pressed relief authorities consider medical care as secondary to food and shelter in the relief budget.

Social need has caused the development of a trend towards broadening the coverage of public medical service beyond the totally indigent to the medically indigent, the group of self-supporting families who cannot afford to pay for a large sickness bill. ${ }^{45}$ 'Thus, the American Medical Association now defines two groups as eligible for public medical care: the relief population who would need complete service, and the families earning up to $\$ 3,000$ who would need varying degrees of public sickness aid. ${ }^{46}$ The full significance of such a trend may be gleaned from the findings by the National Resources Committee that fully $92 \%$ of all the families earn less than $\$ 3,000$. Parallel to this extension in medical relief, has been the realization that insurance facilities would permit most families of modest income to avoid public care. We may expect an increasing awareness by interest groups that health insurance will ease the present pressure on the property tax which now largely finances medical relief.

The wide development of voluntary, health insurance, described elsewhere in this symposium, has tended to make of compulsory health insurance a concept which the public no longer regards as merely a foreign importation. The state workmen's compensation laws, with their increasing emphasis upon medical care, have also been considered a precedent for compulsory health insurance, especially by organized labor. President William Green of the American Federation of Labor has even suggested that health insurance be brought about by simply widening the scope of the present state workmen's compensation systems. On the whole, compulsory health insurance is much less radical an innovation than its opponents portray it to be.

Grants For Temporary Disability Compensation. This title ${ }^{47}$ provides for federal grants to state disability compensation systems. Almost all the states have had some years of experience at administering a limited type of disability compensation, namely,

“ AMA Bureau of Med. Econ., Care of the Indigent Sick (1936).

"Davis, Public Medical Services (1937) 13.

- AMA Bureau of Med. Econ., Factual Data on Medical Economics (1939) 66.

${ }^{47}$ Nat. Health Bill, tit. XIV. 
disability from work accidents or occupational diseases, under the workmen's compensation laws. Since the commencement of unemployment insurance payments, a demand has arisen for disability compensation on the part of the workers, for they see no common sense in the distinction between economic unemployment and sickness unemployment. The American theorists also attach importance to the present federal-state unemployment insurance program in so far as a disability law is concerned. The majority of our students hold that disability compensation should be administered by the unemployment insurance systems, so as to extricate the doctors from their difficult position, betwixt the patient urging liberal certification and the administration pressing for strict certification, commonly found abroad where dis-. ability payments have developed as an integral part of the health insurance laws. In that sense, the present federal-state unemployment compensation system may be considered a direct forerunner of the disability title in the Wagner Bill.

\section{The Societal Forces IN THE Background}

Behind the events and the legislative history sketched above lies a group of broad societal forces which have created the problem calling forth these laws and proposals, and which have also affected the suggested techniques for solution. The main factor in this causal complex is, undoubtedly, the cultural lag in our health practice which the Technical Committee on Medical Care has conveniently measured in terms of unnecessary deaths and preventable disease. Cultural lag is the maladjustment caused by the universal tendency for scientific discoveries to proceed at a faster pace than the necessary changes in our political and social institutions. These maladjustments may be described as follows:

a. The scientific advances in medicine have increased the cost of health care beyond the personal means of many families, and the community means of many local governments.

b. The new emphasis on prevention and early treatment of disease has been hampered by the traditional ${ }^{48}$ fee-for-service system which discourages the consumer from such early care.

c. The progressively increasing accumulation of medical knowledge has made it difficult for the practitioner to keep up with these advances.

d. The modern requirements for expensive capital equipment, such as $\mathrm{x}$-rays, has made the old private practice inadequate, creating a need for the medical workshops-hospitals, rural health centers, and group clinics.

e. The use of the division of labor principle in the health field (differentiating dentistry, public health work, surgery, etc.) necessitated by the vastness of medical knowledge, has created problems of co-ordination and many jurisdictional disputes. ${ }^{40}$

\footnotetext{
${ }^{48}$ But Shafer, The American Medical Profession, 1783 to 1850 (1936), gives evidence of the early existence of "family contracts."

${ }^{19}$ One important jurisdictional dispute may be described. In earlier days, public hcalth work consisted of impersonal environmental measures, such as sewage disposal and water control, but modern public health practice has become personal (maternal and child hygiene) and even curatiye (syphilis control). Although the medical societies were the prime forces in the enactment of early public health legislation, the
} 
In addition to causing this social lag, these technical advances, due to the new, profound, public respect for medicine's possibilities, have brought into the health picture an important social force for reform-a widespread public demand for health services. It is hard to realize that only a century ago, highly intelligent persons were of the opinion that doctors had nothing to offer to the sick. In the words of Shryock, the medical historian: "There was little concern in earlier periods (i.e., before I880) as to whether or not all members of a community receive the attendance of a regular physician. . . . Few people complained in 1850 that they had no access to a hospital. They were only too happy to stay away from them."50 This popular demand for modern medicine, plus the spectacle of only the richer families or the wealthier geographical areas being able to receive its benefits, plus our profoundly democratic tradition for equal opportunities to good living, obviously adds up to a powerful force for health reforms. Significant is the approach to the Wagner Bill by George St. J. Perrot, the secretary of the Interdepartmental Committee: "In essence the National Health Program aims to destroy the correlation between the receipt of health service and income."51

Another element, a political one, also has had an important bearing on the background of the Wagner Bill. This is the greater acceptance today of the governmental instrument as a means for social and economic reforms. The shock of the depression has jolted the traditional American laissez-faire philosophy, and now the average voter probably has much less objection to the further entrance of government into the health field. In this trend, the medical societies have not wholly participated for a host of reasons. The colorful language from a standard history of medicine may be quoted, for it differs only in degree of exuberance from sentiments commonly found in medical journals: $:^{52}$

"The objections of conservative practitioners to socialized or standardized medicine are that the people have already been cozened, stultified, nagged and enslaved by a complex network of superimposed laws and regulations, which are not true codified expressions of total public sentiment, but defeat their own object by encouraging evasion, chicanery, hypocrisy, vice, vulgarity, and corruption of the young; that to apply this principle to the practice of medicine is to degrade the physician to the level of a unionized vassal, destroy his individuality, encourage insolence of office and supercilious bureaucracy, with mere conventional handling or neglect of patients; in brief, to expose the science and art of medicine to the coxcombery of impertinent supervision by lay meddlers of Citizen Fixit type."

The federal government has come to play a principal role in these changing popular conceptions of the place of government. The dangers of overcentralization at Washington are real and have often been pointed out, but certain forces are operating to make at least federal financial grants necessary in many fields. The

\footnotetext{
new public health service has encroached on the practitioner's economic domain and has set up a definite and well-known tendency within the medical societies towards the restriction of public health activities.

${ }^{80}$ Shryock, Development of Modern Medicine (1936) 37 r.

${ }^{61}$ Health as an Element in Social Security (March, 1939) 202 ANNals 136.

s2 Garpuson, History of Medicine (4th ed., 1929) 797.
} 
most important force is the inability of the states and local governments to find tax funds from which to finance new governmental benefits, because of their reliance on the property tax, adequate for the days of the "police state" but inadequate for the new "welfare state." After a discussion of the need for the county unit in rural public health work, Professor Lancaster goes on to say that "yet almost no rural county has organized such a unit of its own will." ${ }^{3}$ The Lynds, scrutinizing social change in a typical American small city, made a similar comment to the effect that health innovations in "Middletown" generally came from the outside. ${ }^{54}$ Realists like Beard recognize the evils of centralization but also realize the necessity of some federal intervention; the problem, to them, is to develop suitable techniques, such as federal grants-in-aid, government personnel training, advisory councils, merit systems, so as to avoid the dangers, and yet to retain the values, of federal participation. ${ }^{55}$ Some consideration of the long history of our "state rights" controversy suggests that the opponent of S. 1620 who argues that the job belongs to the states and not to the federal government, really hopes that the job will not be done at all.50

\section{Summary}

It appears from our survey of the earlier events in the agitation for health reforms that the Wagner Bill is by,no means a sudden development. Senator Wagner's bill would not be considered so seriously today if the public had not felt earlier agitations for reform. Nor can we consider the provisions of the Bill to be revolutionary. We have seen that the public health and hospital construction titles of the Bill are merely another step, albeit a long step, in the orderly development of existing federal health work, while the federal grants for medical care, and the disability compensation program, cannot be thought of as radical innovations, for they, too, have a broad body of precedent. After a consideration of the broad societal forces. in the picture, attempts to explain away the Bill in terms of personal ambitions or of political expediency seem the product of superficial and perhaps wishful thinking. It is evident that the basic causation lies in the maladjustments created by the advances in the medical sciences, the deep desire of the public for the benefits of medical knowledge, and the average voter's acceptance of governmental activities in health work, especially on the part of the federal government.

\footnotetext{
s3 Lancaster, Governacent in Rurai America (1937) 339.

* LYND, Middletown in Transition (1937) 399.

ss BeArd, C. \& W., Akgerican Leviatran (1930) 675.

${ }^{86}$ See, for a comment on this point, Clark, The Rise of a New Federalisa (1938) p. X.
} 